\title{
The Competency Based Approach in Cameroon Public Secondary Schools: Modes of Appropriation and Constrains
}

\author{
Lilian F. Wiysahnyuy, Ph.D* \\ Higher Teacher Training College, The University of Bamenda, Po Box 39, Bambili Cameroon
}

*Corresponding Author: Lilian F. Wiysahnyuy, Ph.D, Higher Teacher Training College, The University of Bamenda, Po Box 39, Bambili Cameroon

\begin{abstract}
In Cameroon, after experimenting on the Objective Based Approach (OBA) and weighing its contextual inadequacies for many years, recourse has been made to another teaching approach, the Competency Based Approach (CBA). Teachers in secondary schools whether socialized or not in the approach are compelled to master and use it as a mode of instruction. The switch to this new teaching approach leaves some unattended questions. Are the teachers equipped and ready for the new approach? What are the challenges to meeting the target objective of the approach? Based on these puzzling circumstances, this paper was designed to examine the various ways by which teachers acquire knowledge and skills on the use of CBA and the attendant challenges they face in implementing it. The research design used for the study was a cross sectional survey. Convenient and purposive sampling techniques were used to select a sample of 145 respondents from five public schools: Government Bilingual High School (GBHS) Downtown Bamenda, GBHS Atiela, GBHS Bamenda, GBHS Bayelle, and GBHS Bamendankwe in Bamenda Municipality. The instrument used for data collection was a questionnaire. Data was analysed using descriptive statistics. The findings revealed that an appreciable percentage of teachers graduated from the training colleges before the CBA was introduced in the Cameroon school system. Majority (96.5\%) attested to the fact that they acquired basic knowledge and skills of CBA through seminars, conferences and workshops which were not really frequent to keep them abreast with the dynamics in the art of the model. It was noticed that majority of the teachers found it difficult to implement the CBA because of inadequate knowledge and skills, overcrowded classrooms, limited teaching hours, the bogus nature of the syllabuses and insufficient pedagogic and learning materials. The study suggest that teachers need diverse professional development activities like in-service training, seminars, conferences, workshops, and individual research to continually appropriate, adapt and use dynamic trends of CBA.
\end{abstract}

Keywords: Approach, Based, Competency, Learning, Teaching

List of Abbreviations: CBA: Competency Based Approach, CBE: Competency Based Education, CBET: Competency Based Education and Training, CBL: Competency-Based learning, CBI: Competency-Based Instruction, CBP: Competency-Based Programs, GBHS: Government Bilingual High School, OBA: Objective Based Approach, PBA: Performance Based Approach

\section{INTRODUCTION}

In recent times, the Competency Based Approach (CBA) has gained grounds in the academic world. In fact, it is no longer vogue to teach with the purpose of restoring knowledge and or applying isolated know-how. It is rather mandatory that learners are confronted with problem situations which they need to solve. Through this approach the learner will not only acquire knowledge but also use it in a meaningful way in various situations of life, work and family, social and even professional situations. This reform has brought about profound changes in teaching practices as the teacher becomes a true mediator between the learner and the knowledge. In order to achieve this competence objective, secondary schools in Cameroon chose, after the experience of programs by content and objective, to follow the path of the CBA. This switch is important as it raises a crucial concern on whether or not teachers are trained to adjust to the demands of the new dispensation. It is on the basis of this puzzle that the paper has been designed to examine the various ways by which teachers acquire knowledge and skills associated with the use of CBA and the challenges they face in implementing it. 


\section{BACKGROUND AND LITERATURE}

Modern competency-based education and training movements began in the United States of America when efforts were made to reform teacher education and training in the 1960s (Hodges \& Harris, 2012). Competence Based Approach (CBA) is currently an emerging concept in Cameroon educational system. The shift in teaching in Cameroon educational paradigm has propelled the gradual move from Objective Based Approach (OBA) also called the communicative approach (CA) to the CBA over the years. Currently, the CBA is used in public secondary schools in the country. According to Tabe (2019), this current trend from the OBA to the CBA should normally go alongside with an alteration of the syllabus approach, course objectives, material designing and more especially instructional material development which for many researchers like Henrichsen (1983) and Treffgarne \&Mbaye (1993) recognised to be trivial and a problem area for teachers. As with any new concept there is no one acceptable definition of this term under operation. The most important thing in the CBA is for the learner to be engaged actively in all aspects of knowledge acquisition, skills development and professional behaviours that need to be demonstrated and practiced in a specific discipline. According to Bashar (2013), CBA may also be viewed as Competency Based Education (CBE), Competency Based Education and Training (CBET), Competency-Based learning (CBL), Competency-Based Instruction (CBI) and Competency-Based Programs (CBP). It can also be used interchangeably with the Performance Based Approach (PBA).

Garavan \& McGuire (2001) acknowledge that the term "competence" has no generally accepted operational definition. According to them, competence is "an action, behaviour or outcome which a person should be able to demonstrate". This definition focuses on what a person can do (output). Kirschner et al. (1997) view competence as the ability to choose and use the attitudes, knowledge and skills that are needed for a performance at a desired level. Kouwenhoven (2003) for his part sees competency as the capability to choose and use an integrated combination of knowledge, skills and attitudes with the intention to realize a task in a certain context while personal characteristics such as motivation, self-confidence and willpower are part of that context. The National Post-Secondary Education Cooperative (2002) refers to competency as the combination of skills, abilities, and knowledge needed to perform a specific task. In spite of the variation in the definitions, they stress the fact that competence is both a physical and an intellectual ability to do something well through repeated experiences. All these indicate that when implementing CBA in institutions of learning three aspects; knowledge, skills and attitudes have to be integrated together in all learning activities. According to Savage (1993), CBA is a functional approach to education as it emphasizes life skills and evaluates mastery on skills, necessary for an individual to function proficiently in a given society. Such a shift has pedagogical implications as Rutayuga (2014) noted that CBA requires a shift from assessing a set of learning contents to assessing each learning outcome. Similarly, Wood (2001) insisted that the move towards competence based rather than content based approach necessitates student-centred teaching and learning.

The Cameroon Ministry of Basic Education (2004) had distinguished three main components of the competence to be taught: subject competence (knowledge), transversal competence (knowledge resulting from all the subjects in a child's learning) and life competence which results from the development of the right attitudes, behaviour, and problem solving skills for real life situations. Richard (2006) for his part identifies the nature of objectives according to the CBA. To him objectives are broken into narrowly focused sub objectives, sothat both teachers and students can get a clear sense of progress. Richards and Rodgers (2001) further opines that each approach needs specific teaching materials in order to realize the aim of its foundation. Therefore, for the implementation of the CBA to be effective, the instructional materials must be the ones that can motivate the learners and provide information in interesting way, bring the real life situation and cultural information to the classroom, supply learner with real exposure to the target language, and meet the needs of the learner. The CBA advocates the learner-centred approach in which the learning process is central. Field and Drysdale (1991) point out some of the aspects of a learner-centred approach such as the use of individualized materials, flexible learning time and continued feedback. In this regard, the implementation of CBA should ensure that all aspects of a learner- centred approach are included in the learning process. The Learning environment in the CBA is therefore directed towards the development of competencies at the end of any study program (Kirschner et al, 1997). 
In the CBA, the focus is to enable learners to master the knowledge, skills and attitudes needed for the world of employment and general life. According to Rogiers (2004), the CBA relies on three fundamental objectives: firstly, to emphasize the competencies that the student must master at the end of each school year and at the end of compulsory schooling, rather than stressing what the teacher must teach. Secondly, to organize the learning outcomes in the best way so as to bring their students to the level expected. Thirdly to entrust the responsibility for learning to the student who has to build his or her own knowledge through means made available by the teacher. According to Boutin (2004), the student becomes a learner who must suggest ideas first, have the desire to know and learn, organize work using new technologies, assimilating new learning methods, and looking for new information. The new role of the teacher consists in encouraging the learners to acquire the knowledge, which must be facilitated but not mechanically transmitted, and entrusting the preparation of certain tasks to the students. In CBA, a teacher is supposed to switch from the role of an expert who transfers knowledge to a coaching role of facilitating and guiding the learning process (Biemans, Nieuwenhuis, Poell, Mulder \& Wesselink, 2004). This means teachers implementing this approach encourage learners to be creative, ensure the planning and organization of activities, and suggest ideas without imposing them on the learners. The teacher is required to be active in supporting the learning process rather than transferring contents. According to Zineb, Soumia, Souad \& Karim, (2017), in implementing the CBA, the teacher should use didactical approach that is based on the facilitation of active learning including group work, presentations and self-study. According to Anane, (2013), CBET or CBA demands a different approach to teaching and even assessment and certification. This is because conceptually, CBA is different from the traditional system. It is based on defined competency standards which are industry oriented. The education and training is more learnercentred. This means that more emphasis is placed on the learner's role in the learning process than teacher-centred. Anane further highlights that the various facilitation methods that are employed for the CBET programmes are direct instruction method, discussion method, small group method, problem solving method and that teachers acquire the knowledge of CBA through seminars, workshops and research.

\section{ChallengeS OF EFFECTIVE IMPlementation OF CBA}

Mahamat (2011) studied the implementation of CBA in some primary schools in Kousseri, Far North Region of Cameroon and realized that the approach is not being implemented effectively due to its novelty in the educational system and the teachers' indifference about the new visions and competences. His student-respondents comment that most competences in their learning are irrelevant for their socioeconomic insertion. He further states some of the challenges as follows; most teachers continue to use the explanation method, they display poor mastery of the method, the large class-sizes which impede the individualisation of instruction and assessment strategies, and the lack of adequate didactic materials. Aschcraft (1994) for his part reveals that the sources of challenges in implementing CBA comprise assessment and classroom management. Competency Based Approach is learnercentred, hence small class sizes are preferred to enable effective use of CBA facilitation techniques. According to Makunja (2015), the ideal CBA class size is between 40-50 learners. Currently in most of the institutions in Tanzania, the average class size is a hundred students and above which restrains teachers from attending to individual needs. Samia \& Nadia (2012) studied problems facing teachers in the implementation of the CBA in teaching Writing. They agree that there are difficulties in teaching Writing under the CBA as participants argued that teaching Writing under the CBA is a hard task. In addition, the teachers confessed that these problems touched them and they fell unable to overcome them because they lack sufficient information related to the CBA. Makunja (2015), investigated the challenges facing teachers in implementing competence base curriculum in secondary schools in Tanzania and found out that teachers faced a variety of challenges that impeded the effective implementation of competence-based curriculum in teaching and learning especially lack of effective training on the use of the CBA.

Hatmanto, (2011) adds that the Implementation of CBA is ineffective because of lack of readiness among the learners and teachers. The ideal condition of CBC demands that both facilitators and students be ready to undergo the teaching and learning process in class, but in reality, the opposite condition happens. According to him, there are some students and teachers who are not ready to learn and teach respectively and this makes it difficult for the CBA to be fully implemented. Another challenge according to Badan \& Biklein, (2003) in Msuya, (2016) is that students attending the 
competence based curriculum class be proactive, unfortunately some students still maintain themselves as passive learners. In this situation, it becomes the teachers' responsibility to encourage them to be more active. Garavan \& McGuire, (2001) reiterate that the challenge comes from students being less "tuned in" in class whereas it is the responsibility of the teachers to stimulate the formers' meta-cognitive skills. From this context, it is clear that the shift from knowledge based to the CBA involves not only teachers to change their mind-sets but also students.

Assessment is also a big issue faced by the facilitators during implementation of the CBA. It is more difficult to assess students' performance in the CBA class than in the conventional class. This might be as a result of the class size or better still the number of students per class. Hatmanto (2011) argues that in the conventional class, premium is given to the students' hard skills through the fixed mechanism of examination, but in the CBA, teachers have to assess both hard and soft skills of the learners. The issue of using students' assignments, projects, student-self assessments, portfolio, tests and examinations as the instruments for collection of student evidences on attainment of knowledge, acquisition of skills and attitudes seem to be a challenge to the facilitators. Hatmanto emphasizes that the hard skills of students can only be assessed through their learning tasks on daily basis which is really time consuming. Another challenge of implementing the CBA is on the side of the teacher's changing roles. It can easily be overlooked how much the role of teacher and students changes, when CBA is implemented (Jellema, 2003). In this paradigm shift, the teacher is supposed to switch from an expert role to transferring knowledge towards a coaching role and guiding students' learning processes. Students are supposed to take self-responsibility for their learning whereas the teacher becomes the facilitator. This requires totally different attitudes for both parties,perhaps even a paradigm shift. This challenge is related to professional development. Anane (2013) holds that unless initial training and follow up assistance is provided for these facilitators on periodic bases,there is a tendency for teachers to teach as they were taught. In this case CBA trainers quickly slip back into the role of the traditional teachers. This is due to the fact that, it is the same teachers who handle the two systems: Traditional and CBA. Switching from one role to the other might pose a serious challenge for some teachers.

Although there exist rich literature on the CBA worldwide, its application in Cameroon is still wanting. From the state of the art in research on the CBA, it is evident that many researchers have attempted to clearly expatiate on what the CBA is, and some of the challenges to effectively implement it in the school system. On the basis of this, the paper is aimed at finding out how teachers in secondary schools in Cameroon specifically in Bamenda municipality acquire knowledge and skills on the use of the CBA in enhancing the teaching-learning process and the challenges they face in implementing this approach.

\subsection{Research Questions}

1. Which are the various ways by which public secondary school teachers in Bamenda municipality acquire knowledge and skills on CBA?

2. What are the challenges public secondary school teachers in Bamenda municipality encounter in implementing the CBA?

\section{Methods ANd Procedure}

The design used in this study was a cross sectional survey. Convenient and purposive sampling techniques were used to select a sample of 145 respondents from Government Bilingual High School (GBHS) Downtown Bamenda, GBHS Atiela, GBHS Bamenda, GBHS Bayelle, and GBHS Bamendankwe in Bamenda Municipality, North West Region of Cameroon (See table 1). Public schools were chosen purposely to find out what the Cameroon government in general and the educational stake holders have put in place to train the teachers since majority of the teachers in these schools are trained by the Cameroon government with First Grade (DIPES I) and Second Grade Secondary Schools Teacher Training Diploma (DIPES II), see table 2.Use was made of the teachers present in schools as of the time of data collection. The instrument used for data collection was a semi structured questionnaire which was made up of closed and open ended items. The questionnaire was made up of three sections comprising; demographic information, training on the CBA and challenges faced in implementing the CBA. Respondents were expected to choose the responses that fitted their views as well as personal opinions where necessary. 
The Competency Based Approach in Cameroon Public Secondary Schools: Modes of Appropriation and Constrains

A pilot test was carried out to ascertain the reliability of the instrument. The instrument was administered in the various schools with the help of research assistants within a period of ten days that is two days each per school. Most of the respondents took the copies of the questionnaire home and returned them the following day. The consents of the participants were solicited and only those who consented filled the copies of the questionnaire. The respondents were assured of confidentiality and the researchlacademic purpose of the exercise. Data were analysed using descriptive statistics specifically frequency count and percentages.

Table1. Distribution of teachers according to schools

\begin{tabular}{|l|l|l|l|l|l|}
\hline \multicolumn{2}{|l|}{ Schools } & Frequency & Percent & Valid Percent & Cumulative Percent \\
\hline Valid & GBHS DOWNTOWN & 20 & 13.8 & 13.8 & 13.8 \\
\cline { 2 - 6 } & GBHS BAMENDA & 46 & 31.7 & 31.7 & 45.5 \\
\cline { 2 - 6 } & GBHS BAYELLE & 45 & 31.0 & 31.0 & 76.6 \\
\cline { 2 - 6 } & GBHS ATIEALLA & 34 & 23.4 & 23.4 & 100.0 \\
\cline { 2 - 5 } & Total & $\mathbf{1 4 5}$ & $\mathbf{1 0 0 . 0}$ & $\mathbf{1 0 0 . 0}$ & \\
\hline
\end{tabular}

Table2. Distribution of teachers according to qualification

\begin{tabular}{|l|l|l|l|l|}
\hline \multicolumn{2}{|l|}{ Qualification } & Frequency & Percent & Cumulative Percent \\
\hline \multirow{4}{*}{ Valid } & DIPES I & 70 & 48.3 & 48.3 \\
\cline { 2 - 5 } & DIPES II & 65 & 44.8 & 93.1 \\
\cline { 2 - 5 } & OTHERS & 10 & 6.9 & 100.0 \\
\cline { 2 - 5 } & Total & 145 & 100.0 & \\
\hline
\end{tabular}

\section{RESULTS AND FINDINGS}

The results and findings are presented following the research questions

Research Question One: Which are the various ways by which public secondary school teachers in Bamenda municipality acquire knowledge and skills on the CBA?

Table3. Teachers' responses on their training and use of $C B A$

\begin{tabular}{|l|l|l|l|l|}
\hline & Agree & \% & Disagree & \% \\
\hline $\begin{array}{l}\text { 1. I have some knowledge on what CBA } \\
\text { is all about. }\end{array}$ & 140 & $96.5 \%$ & 05 & $3.5 \%$ \\
\hline $\begin{array}{l}\text { 2. The CBA was introduced when I was } \\
\text { in the training school. }\end{array}$ & 76 & $52.4 \%$ & 69 & $47.6 \%$ \\
\hline $\begin{array}{l}\text { 3. I was trained on how to use the CBA in } \\
\text { teaching when I was in the training } \\
\text { school. }\end{array}$ & 71 & $50.1 \%$ & 71 & $49.9 \%$ \\
\hline $\begin{array}{l}\text { 4. I have been attending conferences and } \\
\text { seminars on how to use CBA in teaching. }\end{array}$ & 23 & $15.9 \%$ & 122 & $84.2 \%$ \\
\hline $\begin{array}{l}\text { 5. I have been participating in workshops } \\
\text { on the use of CBA in teaching. }\end{array}$ & 44 & $30.3 \%$ & 101 & $69.6 \%$ \\
\hline $\begin{array}{l}\text { 6. } \\
\text { seminars/workshops to enhance our } \\
\text { knowledge and skills on the use of CBA } \\
\text { in the teaching-learning transaction. }\end{array}$ & 46 & $52.4 \%$ & 69 & $47.6 \%$ \\
\hline $\begin{array}{l}\text { 7. I read literature on CBA to improve on } \\
\text { my knowledge and skills. }\end{array}$ & 38 & $26.2 \%$ & 107 & $75.8 \%$ \\
\hline
\end{tabular}

The results on table 3 indicate that, an overwhelming majority $(96.5 \%)$ of the respondents had some knowledge on what CBA is all about. When quizzed on whether the respondents were in the training school when CBA was officially introduced in the Cameroon secondary school system, most (52.4\%) accepted. It was realized that just half of the respondents indicated that they were trained on how to use CBA when they were in the training school. This is obvious because a slight majority of the respondents accepted that CBA was introduced when they were in the training school. The results on table 3 also indicates that less than $50 \%$ of the respondents indicated that they had been attending conferences, seminars and workshops on how to use the CBA in teaching. The respondents were also asked whether the respective schools organize seminars/workshops to enhance their knowledge and skills on the use of the CBA in the teaching-learning transaction, a relative majority (52.4\%) accepted. 
The Competency Based Approach in Cameroon Public Secondary Schools: Modes of Appropriation and Constrains

When the respondents were questioned whether they read literature on CBA in order to improve on their knowledge and skills on the use of this approach in teaching, an insignificant percentage (26.2\%) of the teachers confirmed this.

\subsection{Rating of Teachers Knowledge of the CBA}

The respondents were asked to rate the level of their knowledge of the CBA, the statistics are presented on table 4 and figure 1

Table4. Frequency distribution of teachers ratings on their knowledge on the use of CBA in teaching

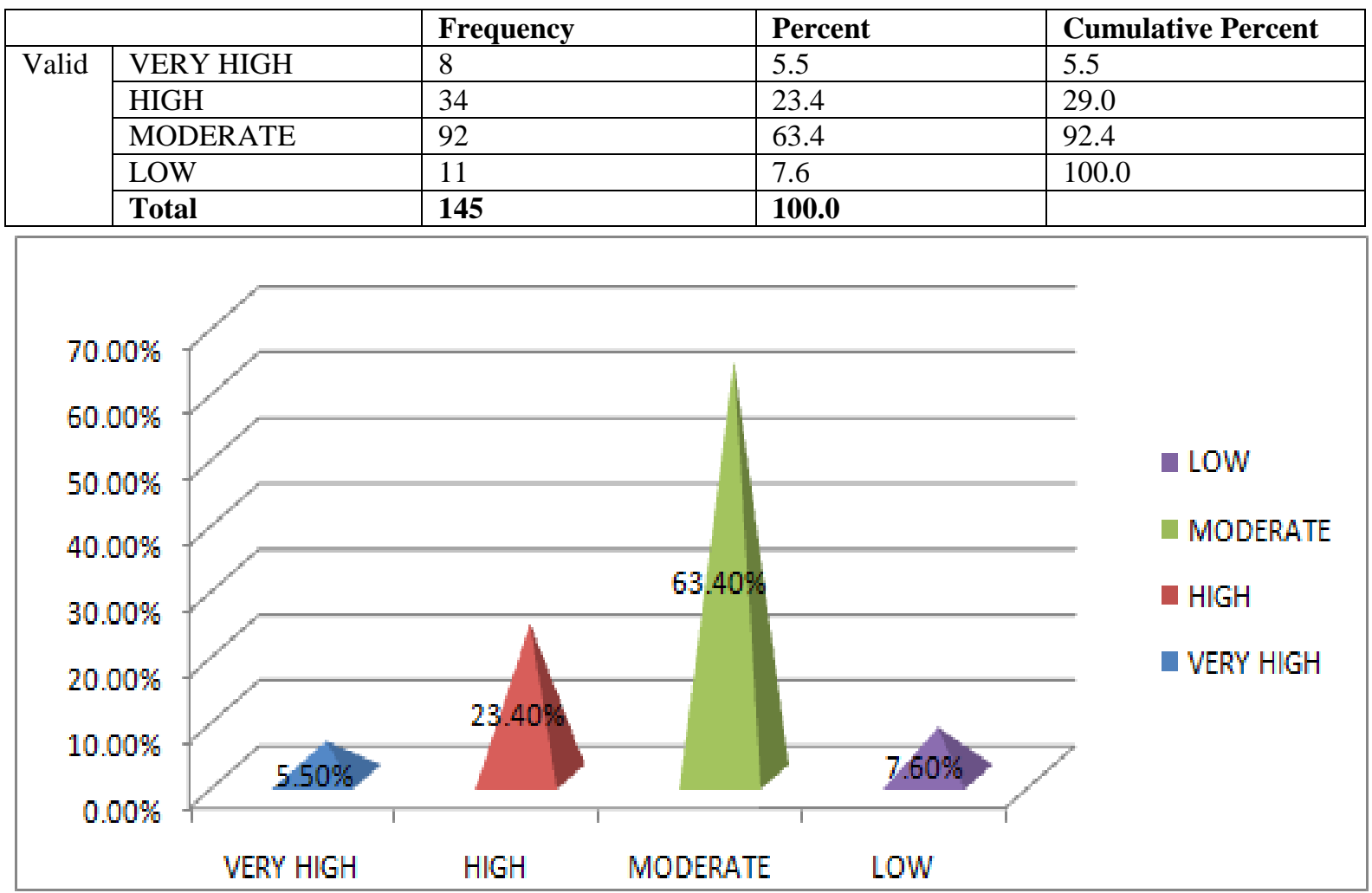

Figure1. Teachers' ratings on their knowledge of the CBA in the teaching-learning transaction

The results on table 4 and figure 1 show that an insignificant percentage $(5.5 \%)$ of teachers rated their knowledge on the use of CBA as very high, some (23.4\%) rated their knowledge as high, majority $(63.4 \%)$ rated as moderate, while a few (7.6\%) rated their knowledge on CBA as low. This indicates that at least majority of the teachers have basic knowledge of whatthe CBA is all about.

The respondents were asked to describe what they knew about the CBA, some of the common responses were that the CBA is an approach which focuses on the learner-centred strategies of the teaching-learning transaction, which have outcome that need to be attained at the end of the lesson. Some were of the opinion that it is a type of teaching whereby activities have to be linked to learners' daily activities. Others held that CBA deals with practicalities in the course of teaching that is encouraging students to carry out assigned tasks. Some of the respondents said 'it is a new approach of teaching/learning process in schools', someaffirmed the approach has an impact on the lives of studentsas it has ensured a better understanding of the subject matter. Some teachers said this approach deals with students' ability to solve real life problems. While others were of the opinion that the CBA deals with real life situation and enhances creative and critical thinking in students with the use of successive questions. These responses indicate that CBA entails a whole lot of dynamicsand teachers have diverse ideas of what it is geared at.

Research Question Two: What are the challenges public secondary school teachers in Bamenda municipality encounter in implementing the CBA?

The respondents were asked whether they faced challenges on implementing the CBA and an overwhelming majority (75.9) accepted while a few (24.1\%) of them said they had no difficulties using the CBA in teaching. This is presented on table 5 and figure 2. 
The Competency Based Approach in Cameroon Public Secondary Schools: Modes of Appropriation and Constrains

Table5. Frequency distribution of teachers' responses on whether they face challenges in using CBA

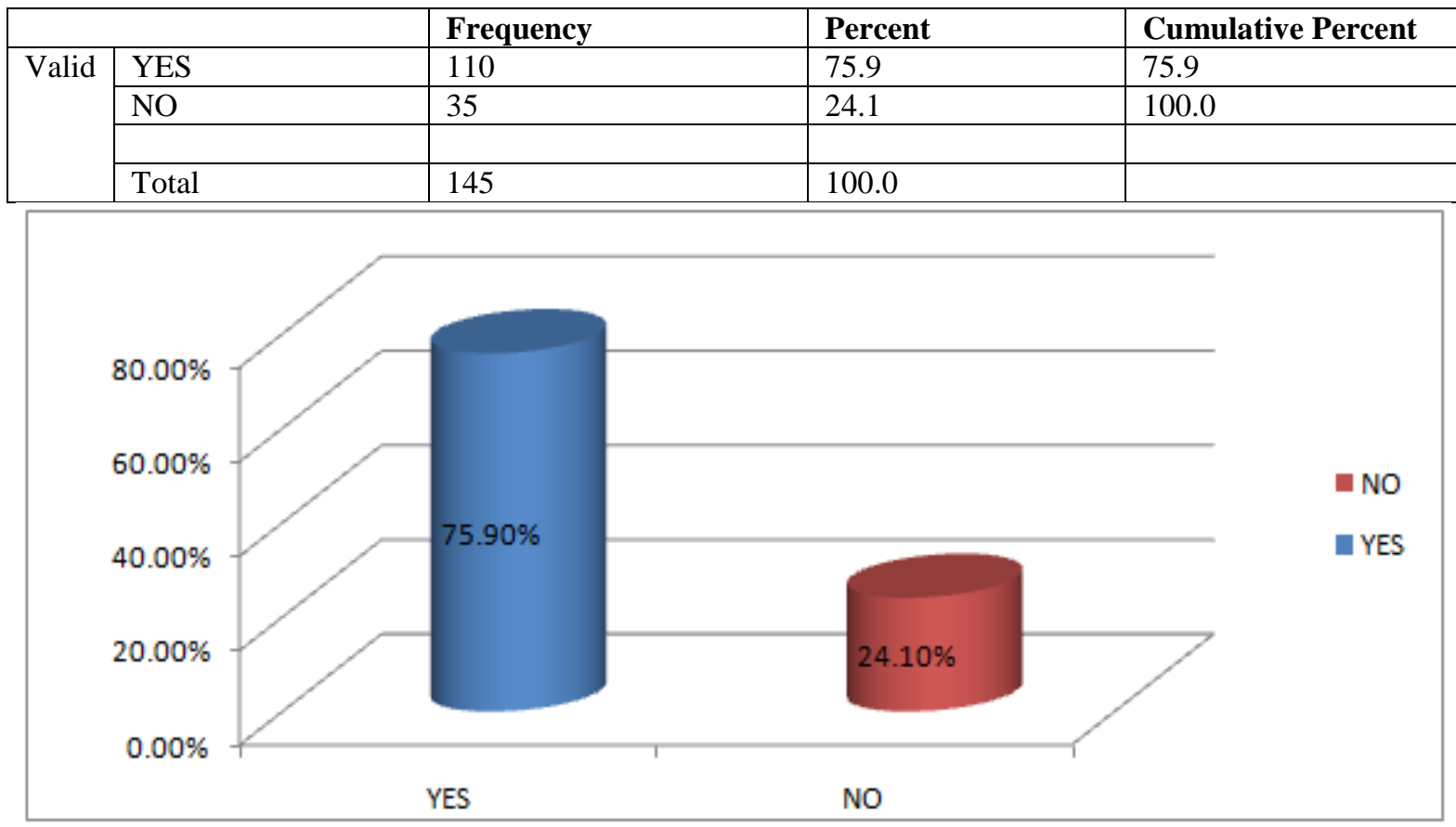

Figure2. Teachers responses on whether they face challenges on the implementation of the CBA

An open ended question was asked to the respondents to state some of the challenges they face in implementing CBA. Some of the challenges they highlighted were; overcrowded classrooms, lack of concrete teaching aids, inadequate knowledge on how to use this approach, lack of textbooks, students negative attitudes towards assignments, difficulties relating some lessons to real life situations, background of students, difficulties in producing teaching-learning aids in some lessons and limited teaching hours. Some indicated that the General Certificate of Education (GCE) Ordinary and Advanced level evaluation are not based on this technique. Other teachers said the CBA is not applicable in all subjects, some complained of finances and constant revision of CBA related issues which makes it difficult for them to really know what is expected of them during the teachinglearning transaction.

Of all the highlighted challenges, it was realized that most $(85 \%)$ of respondents asserted that the over-crowded nature of the classrooms made it difficult for them to effectively use this approach. They indicated that the student-teacher ratio in most government schools was too high and made it difficult for teachers to consider individual needs in the course of teaching. One of the respondents teaching Geography clearly stated "I find it very difficult to fully implement the CBA in teaching because I teach at least ninety-five students per class. There are times I prefer using the lecture method so as to complete my scheme of work before the end of the academic year." This is an indication that some teachers are concerned more with how fast they can cover the schemes of work assigned to them than the learning outcomes of the students.

A majority (76\%) of the respondents also emphasized that effective implementation of CBA is time consuming and the number of teaching hours allocated for some subjects per week is not sufficient. One of the respondents reported

"I am a Biology teacher, and my scheme of work for each term and year is too lengthy than the number of hours allocated for this subject. I need to teach the content and at the same time carry out practical lessons with the students but the duration on the time table is limited. At times I decide to give lectures in some of the lessons so as to catch up with time. If I really want to focus on learner-centred methods all the time, I will not go anywhere before the end of the year".

Some of the respondents clearly stated that they were not well informed on how to use this approach. They further indicated that the approach was introduced when they were already teaching and little has been put in place in terms of seminars and workshops to train them on the implementation of this 
approach. Some who were or went to the training colleges when the CBA was already introduced indicated that they were not properly trained on the specificities of this approach. One of the respondents reported that

"I went to the training college when the CBA was already introduced. Although we were taught the various teaching methods and other relevant issues, I did not really notice any emphasis on the various aspects of the CBA and how the approach could be implemented effectively. Until now I find it very difficult to even state what the CBA is apart from the emphasis on learner-centred teaching methods."

This is proof of the fact that there is still a blind gap between the vision of the CBA and its operational dispositions.

Another open ended question was asked for the respondents to suggest strategies to be put in place to enhance teachers' knowledge on how to effectively use the CBA during the teaching-learning transaction. Summarily, majority proposed that the CBA should be one of the core themes in the teacher training schools where emphasis are laid on the practical not just the theoretical part. Some were of the opinion that on-the-job training should be implemented especially for those who had no formal training on the approach. Others indicated that there should be regular seminars and workshops in schools to improve on teachers' skills and knowledge on the CBA. Some also specified that the student -teacher ratio should be reduced and this can only be done by training more teachers especially in those fields with many students.

\section{Discussions}

The findings of the study indicate that majority of the teachers have basic knowledge and skills on how to effectively use the CBA. These were imbedded from seminars, conferences and workshops held occasionally and sadly, less practical to keep them abreast with the dynamics in the art of the model. The findings corroborate with the work of Anane (2013) which states that teachers can acquire skills on any newly introduced approach of teaching through seminars, workshops on-the-job training and research. Though secondary school teachers listed diverse ways of acquiring knowledge and skills of the CBA, they overlooked the importance of Albert Bandura's social learning theory which is based on observation and modelling. According to Nizam et al (2009), Bandura's Social learning theory could be used in helping teachers to acquire knowledge and skills on the CBA. Bandura (1997) indicates that the information we glean from observing others influence our behaviour. This means that teachers can observe others who are effectively practicing this approach and they model their behaviour. This is really positive because observation of other teachers teaching using this approach will help them to see the practicality of the approach and model them. Observation of others in the art of teaching is an important tool which is encouraged as far as teachers' professional development is concerned. Most teachers fail to teach effectively because they minimize the role of observation in their profession. This is also reiterated by Carroll, Jobling \& Forline, (2003) who state that inadequate field based experiences like observation in pre-service training program and on the job training fail to equip teachers with the practical skills necessary for effective implementation of the CBA.

Although Majority of the teachers indicated to have some basic knowledge on how to use the CBA, some stated that they found it difficult to implement the approach because of inadequate training. This is an indication that teachers need diverse professional development activities like in-service training. This tie(s) with the view of Boudersa (2016) who holds that teachers' professional training and professional development is a necessary ingredient to support innovative and beneficial teaching because most of them come to their career as teachers with little formal professional training or experience in current approaches of teaching. Boudersa further explains that such lack of professional training and professional development of teachers can be a key source for any dissatisfaction in the quality of their teaching to form competent students with the necessary knowledge and skills in the different subject matters. In the present study, the respondents indicated that to enhance their knowledge and skills on the use of the CBA in the teaching-learning process, there is need for inservice training, intensive workshops and conferences. The findings of this study are also in conformity with Darling-Hammond \&McLaughlin (1995) who indicate that teacher training and professional development are central mechanisms for the improvement of teachers' content knowledge, skills and practices to meet high educational standards. These 
findings are in congruence with the Cambridge Professional Development Qualifications (2014) which recognizes the importance of teacher training and professional development by stating that, the most important factor in the quality of students' learning is the quality of teaching gained throughpre-service and in-service programmes. The findings also confirms the work of Cavkaytar, (2006) which emphasis that pre-service training strategies that depend on continuity tune with the new roles for teachers should be offered. Carroll, Jobling and Forline (2003) had foregrounded this position when they concluded that pre-service training programme is very necessary in building teachers knowledge in the implementation of competence based education.

Even though some respondents indicated to have undergone pre-service training where they were trained on the practical aspects of the CBA, some who did not receive this very important part of their training, suggested that for teachers to have adequate knowledge and skills on the CBA, pre-service and in-service programmes should be modified to meet up with the demands of the new approach. This suggestion ties with the ideas of Rosenberg, Sindela \& Hardman, (2004) which suggest the need for teachers to undergo a rigorous training programme in order to possess the vital competencies, abilities, knowledge, and skills necessary to carry out the teaching process in an effective and efficient way. This also matches the findings of Fitch \& Kopp, (1990) who posit that in the case where the teachers are already in the field, in-service training programmes will be necessary to improve their skills, knowledge, and performance competencies associated with the CBA. Teachers who are already on the field will certainly require more professional development programmes to improve on their knowledge and skills on the implementation of the CBA. This aligns with Wiysahnyuy (2019) who emphasizes that to enhance professional development of teachers, there is need to attend conferences, seminars, workshops, short courses and undergo in-service training if need arises to improve on or gain more knowledge on subject matter, teaching techniques, skills and assessment strategies which are in one way or the other related to the CBA. Though the respondents indicated that there is need for training of teachers to improve on their knowledge and skills on CBA, they overlooked the importance of short and long courses which could be offered to teachers to train them on what the CBA is all about and how to effectively implement it in order to attain the anticipated gains.

The findings of this study revealed that teachers face difficulties in implementing the CBA as a result of overcrowded classrooms. This indicate that when the teacher- student ratio is too disproportionate it becomes a serious challenge to effectively implement the CBA. Despite teacher's ability to provide facilitation and coaching tasks at required frequency using the CBA, it was difficult for teachers to pay individualized attention to learners, to motivate and give them stimulus to focus on study because of the overcrowded nature of the class. This is in line with Aschcraft (1994) who asserts that it is very difficult for every facilitator or instructor to develop soft skills to a large number of students when the facilitation is dealing with many students. The findings of this work also tie with that of Harricharan (2011) who states that a teacher often experience many difficulties to attain to individual differences in terms of learning activities and assessment as a result of a large number of learners in a class.The issue of using students' assignments, projects, student-self assessments, portfolio, tests and examinations as instruments for collection of students evidences on attainment of knowledge, acquisition of skills and attitudes seem to be a challenge to the facilitators when they deal with congested classrooms. Equally the findings corroborates the work of Waal (2005) who maintains that it is very difficult to implement a learner-centred approach in teaching in a large class. This study also associate with the study of Bantwini (2010) who states that teachers find it very difficult to cope with a large number of learners in their classes. This indicate that in order to implement CBA effectively the teacher-student ratio should be moderate. This will enable teachers to be able to identify and attain to individual problems during the teaching- learning transaction. According to Makunja (2015), for the CBA to be effectively implemented a class should not go beyond forty learners.

Also, some teachers in public secondary schools in Bamenda indicated that the limited number of hours allocated for their subjects was a great impediment to implement the CBA. Some emphasised that they would have loved to implement the CBA to the fullest but the fact that they have just forty five minutes for each lesson makes some of them to use teacher-centred methods. This observation squares up with the findings of Timothy (2011) who situates that majority of facilitators at schools complain of limited number of hours on the time table and that some teachers are often overloaded 
with administrative responsibilities. Although the CBA requires much time, some teachers lost sight of the fact that they could prepare a number of learning activities for students to work on at home or during their study periods at school. It was also realised that, one of the challenges teachers faced in relation to the implementation of the CBA was inadequate teaching and learning facilities such as computers, laboratory equipment and text books. They emphasized that most students did not have the required text and work books which made it very difficult to handle some of the lessons as teachers were required to copy some of the learning activities on the board. This became a serious issue given the limited hours allocated for the lessons. This finding runs in line with those of Kafyulilo et al (2012) who conclude that CBA is not well implemented in schools that lack teaching/learning resources and to a large extent teachers have continued teaching using the traditional approaches and assessment as a result of lack and inadequate facilities to implement the student centred approach. This findings also tie with ideas of Renitta et al., (2004) who posit that inadequate library services and relevant texts have made students to search for these services outside the institute and this condition affects the students academically as they delay to submit assignments on required time. This shows that the availability of teaching and learning resources are very crucial in the competency based approach of teaching and learning.

\section{CONClusion}

Teaching and learning in Cameroon secondary schools is gradually moving from the traditional based approaches to the Competence Based Approach (CBA) which is largely supposed to be learnercentred. With the introduction of the CBA, teachers in Cameroon schools and colleges are compelled to master and use the approach in facilitating the teaching-learning transaction. This paper was intended to find out the various ways in which teachers in Public secondary Schools in the Bamenda municipality appropriate knowledge and skills on the use of the CBA and the challenges they face in implementing the approach. After collecting data using a semi structured questionnaire, the findings revealed that majority of the teachers acquired basic knowledge and skills on how to implement the CBA through impromptu seminars and workshops which however are infrequent to attain to the desired outcomes. Some indicated that although the CBA was introduced before or when they enrolled in the teacher training colleges, they did not really acquire specific knowledge or engage in practical lessons that were based on the use of the CBA in enhancing the teaching-learning process. Most of the teachers indicated that in implementing the CBA they faced challenges such as overcrowded classrooms, inadequate teaching/learning resources, inadequate knowledge on how to use the approach, limited teaching hours for each lesson, limited professional development programmes, students' negative attitudes towards assignments, problems related to some lessons on real life situations and background of students. These challenges constrained teachers to implement the adopted CBA curricula. If teachers are to succeed in implementing the CBA curricula, there is need for teachers to be involved in rigorous professional development activities like seminars, conferences, workshops, observation of others teaching using the CBA, in-service training and individual research. Though it may be a difficult task, it is necessary for the student and teacher ratio to be moderated to align with the UNESCO standard. It is evident that in most public schools there are some classrooms with more than one hundred students and this is a cause for concern if teachers are really expected to implement the CBA effectively. Teachers also need to be proactive when faced with this challenge of overcrowded classrooms so as not to defeat the objective of the CBA which is learner-centred in nature. School management should design sustainable strategies that would alleviate the challenges that teachers and students encounter so as to enable the effective implementation of the CBA.

\section{REFERENCES}

[1] Anane, A. C. (2013). Competency Based Training: Quality Delivery for Technical and Vocational Education and Training Institutions. International Journal of Educational Research. 2 (2): 5-6.

[2] Ashcraft, M. H. (1994). Human Memory and Cognition. New York: HarperCollins.

[3] Bandura, A. (1997). Self-Efficacy: The exercise of control. New York: W.H Freeman/Times Book

[4] Bantwini, B. D. (2010). How Teachers Perceive the New Curriculum Reform: Lessons from a School District in the Eastern Cape Province. International Journal of Educational Development. 30 (1):83-90

[5] Bashar, A. (2013). Investigating teachers attitude toward adequacy of teacher Training 
[6] Biemans, H., Nieuwenhuis, L., Poell, R., Mulder, M. \& Wesselink, R. (2004). Competencebased VET in the Netherlands: Background and pitfalls. Journal of Vocational Education and Training, 56(4), 523538pp. Retrieved on 8 August, 2015 from http://www.bwpat.de/7eu/biemans etal nl bwpat7.shhtml.

[7] Blakemore, S. (2008). A Competency based approach to RedR's training and learning activities. UK: RedR

[8] Bolívar, A. (2015). Un currículum común consensuado en torno al marco europeo de competencias clave: un análisis comparativo con el caso francés. Revista de la Asociación de Inspectores de Educación de España, Granada, n. 23, p. 1-35

[9] Boutin, G. (2004). "L'approche par compétences en éducation : un amalgame paradigmatique," Connexions, $n^{\circ} 81$, pp. 25-41, https://www.cairn.info/revue-connexions-2004-1-page-25.htm

[10] Carroll, A., Forlin, C., \& Jobling, A. (2003). The impact of teacher training in special education on attitudes of Australian pre-service general educators towards people with disabilities. Teacher Education Quarterly, 30, 65- 79.

[11] Cavkaytar, A. (2006). Teacher training on special education in Turkey. The Turkish Online Journal of Educational Technology-TOJET 5(3)pp41-45

[12] Darling-Hammond, L \& McLaughlin, M. (1995). Policies that Support Professional Development in an Era of Reform. National college of school leadership 76(8) pp 597-604

[13] Field, L. \& Drysdale, D. (1991). Training for competence: A handbook for trainers andteachers. London: Kogan page.

[14] Garavan, T. N. \& McGuire, D. (2001). Competencies and workplace leaning: Some reflections on the rhetoric and the reality. Journal of Workplace Learning. 13(4): 144163, 1366-5626

[15] Hatmanto, E. D. (2011). Challenges in the Implementation of Competency-BasedCurriculum in the English Language Teaching. In; proceedings of TEFL conference, Seoul, South Korea, 15 April, 2011. 10$13 \mathrm{pp}$.

[16] Hodge, S., \& Harris, R. (2012). Discipline, governmentality and 25 years of competency-based training. Studies in the Education of Adults,44(2)pp155-170

[17] Jellema, K. (2003). Competentiegericht leren binnen een AOC. In: M. Mulder, Wesselink, R., Biemans, H., Nieuwenhuis, L. \& Poell, R. (eds.). Compentiegericht beroepsonderwijs. Gediplomeerd, maar ook bekwaam? Houten: Wolters Noordhoff.

[18] Kafyulilo, A. C., Rugambuka, I. B., \& Mosses, I. (2012). The Implementation of Competency -Based Teaching Approaches in Tanzania. A case of Pre- service Teachers at Morogoro Teacher Training College. Universal Journal of Educationand General Studies 1(11): 339-347.

[19] Kirschner, P., Van Visteren, P., Hummel, H., \& Wigman, M. (1997). The design of a study environment for acquiring academic and professional competence. Studies in Higher Education, 22 (2) pp 151-17.

[20] Kouwenhoven, G. W. (2003). Designing for Competence: Towards a Competence-Based Curriculum for the Faculty of the Eduardo Mondlane University. Doctoral Dissertation. Enschede, Netherlands: Twente University.

[21] Mahamat, A. (2011). La pratique de l'approche par Compétences dans les écoles primaires D'application de la ville de Kousseri (région de l'extrême nord/cameroun). SPIRALE. Revue de Recherches en Education, https://spirale-edu-revue.fr/MG/pdf/ mahamat_spialeE_2011pdf

[22] Makunja, G. (2015). Adopting competence-based curriculum to improve quality of secondary education in Tanzania: 'is it a dream or reality'. International Journal of Education and Research.3(11)pp 175-188

[23] Msuya, A.A. (2016).Facilitators and learners' perceptions on the Implementation on competence-based curricula in adult Education programmes in Tanzania, (Master Thesis), University of Tanzania

[24] NACTE, (2008). CBET Facilitation: Guidelines on How to Plan and Facilitate Competence-Based Learning. Dar es Salaam: NACTE.

[25] Nizam. H , Al-zoubi, S. M, Rahman. M. B \& Al-shabatat, A. M. (2009). Competency Based Teacher Education (CBTE): A Training Module for Improving Knowledge Competencies for Resource Room Teachers in Jordan. European Journal of Social Sciences - Vol 10, No.2

[26] Richards, J. C. (2006). Communicative language teaching today. New York: Cambridge University Press

[27] Richards J., \& Rodgers, T. (2001). Approaches and methods in language teaching. New York: Cambridge University Press. http://dx.doi.org/10.1017/CBO9780511667305

[28] Richards, J. C. (2001). Curriculum development in language teaching.UK : Cambridge University Press

[29] Rogiers, X. (2004). L'école et l'évaluation: Des situations pour évaluer les compétences des élèves, France : Edition De Boeck 
[30] Rutayuga, B. A. (2014). The emerging Tanzania concept of competence: conditions for successful implementation and future development. A Thesis submitted to the Institute of Education, University of London in Partial Fulfillment of the Requirements for the Degree of Doctor of Philosophy

[31] Savage, L. (1993). Literacy through a competency-based education approach. Washington DC: Center for Applied Linguistics

[32] Tabe, A N. (2019). Competency-based approach assessment strategies: Theory versus practice in Cameroon. International Journal of Applied Research; 5(4): 142-147

[33] Timothy, V. A. (2011). An assessment of competence-based curriculum implementation in teaching and learning ordinary level physics. The case of Singida municipality, Tanzania. Unpublished Masters Dissertation. University of Dar es Salaam, Tanzania.

[34] Wiysahnyuy, L. F. (2019). Professional Development of Teacher Trainers in the Higher Teacher Training College Bambili (Cameroon). International Journal of Humanities Social Sciences and Education (IJHSSE), vol. 6, no.7, 2019, pp. 55-62.

[35] Woods, E. (2008). Tanzania Case study. In UNESCO Country Profile Commissioned for EFA global monitoring report: Education for all by 2015, will we make it? Paris: UNESCO

[36] Zineb, A.H, Soumia, B., Souad, A. \& Karim, G. (2017). The Application of the Competency-Based Approach to Assess the Training and Employment Adequacy Problem. International Journal of Education (IJE) Vol.5, No.1 PP1-18

\section{AUTHOR'S BIOGRAPHY}

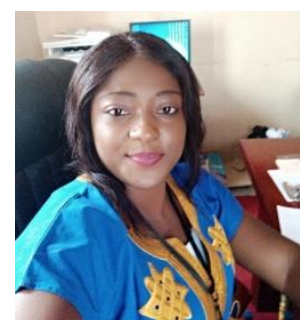

Education.

Dr. Lilian F.Wiysahnyuy, is currently the chair of the Department of Guidance and Counselling, and lecturer in the Department of science of Education in the Higher Teacher Training College, The University of Bamenda in Cameroon. She is a member and a professional development fellow of the International Society for the Study of Behavioural Development (ISSBD), a member of the Cameroon Professional Research Oriented Women Network (CaPROWN) and Cameroon Psychology Association (CPA). Her teaching and research focus on but not limited to Psycho-pedagogy, school counselling and Research methods in

Citation: Lilian F. Wiysahnyuy. "The Competency Based Approach in Cameroon Public Secondary Schools: Modes of Appropriation and Constrains" International Journal of Humanities Social Sciences and Education (IJHSSE), vol 8, no. 1, 2021, pp. 92-103. doi: https://doi.org/10.20431/2349-0381.0801011.

Copyright: () 2021 Authors. This is an open-access article distributed under the terms of the Creative Commons Attribution License, which permits unrestricted use, distribution, and reproduction in any medium, provided the original author and source are credited. 